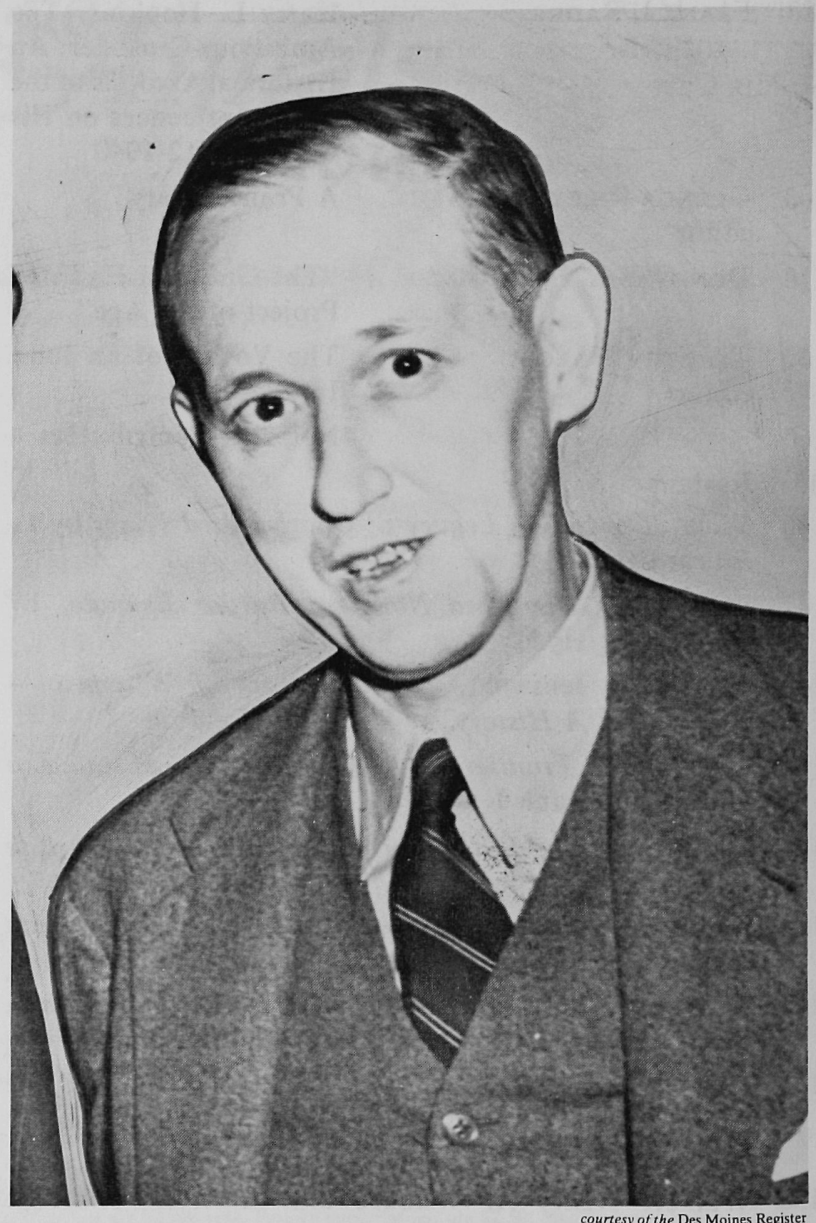

courtesy of the Des Moines Register Harry L. Hopkins 


\section{Harry L. Hopkins, The Ambitious Crusader: An Historical Analysis of the Major Influences on His Career, 1912-1940}

Frank J. Rader

HARRY LLOYD HOPKINS, RENOWNED FOR HIS CURIOUS BLEND of sarcasm and compassion, has received short shrift from American historians. Only Robert E. Sherwood, Searle Charles and Paul A. Kurzman have produced book-length studies of the controversial Iowan, and none has written the definitive biography. Sherwood dwells on the wartime relationship between Hopkins and President Franklin D. Roosevelt; Charles emphasizes the inner workings of the relief agencies run by Hopkins from 1933-1938; and Kurzman's recent study examines his career as a public administrator. ${ }^{1}$

Hopkins, the embodiment of the New Deal's pragmatic reformism, hurtled his sickly frame through the crises of the Roosevelt administrations, slashed red tape, created jobs and played politics, while he assisted business recovery and national preparedness. He also leapfrogged agencies in a conscious effort to realize his personal ambitions, which included succeeding FDR in 1940. Hopkins' rise from a case worker on the sidewalks of New York to a presidential confidant, cabinet member and envoy to Churchill and Stalin, never ceased to amaze him. His efforts brought him power not wealth. But his faith in the Horatio Alger possibilities for swift upward mobility within the American democratic system was confirmed. De-

'Robert E. Sherwood, Roosevelt and Hopkins (New York: Grosset \& Dunlap, 1950); Searle Charles, Minister of Relief, Harry Hopkins and the Depression (Syracuse: Syracuse University Press, 1963); and Paul A. Kurzman, Harry Hopkins and the New Deal (Fair Lawn, New Jersey: R. E. Burdick, Inc. Publishers, 1974). In addition to these books, there are four other excellent sources of biographical information on Hopkins: Hopkins MSS, Microfilm Rolls 1-20, FDR Library; Alfred B. Rollins, Jr., Dictionary of American Biography, Supplement 4, 1974, 391394; Geoffrey T. Hellman, "House Guest," The New Yorker, (August 7 \& 14, 1943), 25-30, 27 30, 32, 34; "Harry Hopkins," Fortune (July, 1935), 59-64, 126, 128. After this article went to press a new biography of Hopkins was published: Henry Adams, Harry Hopkins (G. P. Putnam, 
spite his rise to the second most powerful figure in Americ after 1940, Hopkins maintained his concern for the downtroc den and he never ascribed their misfortune to moral laxity divine retribution.

Harry Hopkins' historical reputation still rests heavily o Sherwood's dual biography, Roosevelt and Hopkins. Th playwright-historian worked closely with Hopkins after 194 when the latter was consumed by his single-minded pursuit $c$ the nation's war objectives. Sherwood did not know Hopkin well before 1940, nor did he examine all of his friend's New Dea papers, and he assumed, quite incorrectly, that Hopkins wa similarly fanatical in his pursuit of the New Deal's social ob jectives before 1940. Sherwood paints a flat, one-dimer sional portrait of a true believer who merely exchanged on crusade for another. ${ }^{2}$ On the contrary, Hopkins was a com plex, multi-layered individual, who juggled many interest and scattered his fire during the halcyon days of the Ner Deal. ${ }^{3}$ As head of the Federal Emergency Relief Administra tion, the Civil Works Administration, and the Works Progres Administration, Hopkins not only organized a national wor relief system, but he also championed social security, unem ployment insurance, public housing, rural rehabilitation, sur plus distribution, foreign trade expansion and national pre paredness measures. Hopkins' accomplishments demon strated his versatility and administrative skills to the presi dent, military leaders, businessmen and liberal reformers. $\mathrm{H}$ impressed most observers with his ability to grasp the essenc of a problem, plan practical measures for its solution, an oversee the expeditious execution of plans. Hopkins was $n$ lightweight functionary, but an ambitious and talented publi servant who saw great opportunities in public service to hel] mankind and advance his own career. The 1920s and 1930 were an important gestative period in the maturation of Harr Hopkins, reformer, politician and charter member of th

${ }^{2}$ Sherwood, Roosevelt and Hopkins, 1, 11.

${ }^{3}$ Balkin Report, December 19, 1934, FDR Library, Hopkins MSS, Roll 19. This is a stud by a vocational adviser who examined the characteristics of several New Dealers and recon mended the job which best suited them. Balkin concluded that Hopkins was one of the "ou standing practical idealists" among the New Dealers who qualified as an administrator of a s! cial service agency or an educational institution. 
"administrative breed." The New Deal experience, in particular, familiarized Hopkins with many national problems and political realities and accelerated his development from an ambitious relief administrator into the selfless assistant president of the war years.

This study will examine some of the leading conditioners of that development: his family and formal education; his progressivism and social work career; his various administrative tasks; his chronic poor health; his political ambitions; and the emergency-charged ambiance of the New Deal years.

Hopkins was born on August 17, 1890 in Sioux City, Iowa, the fourth of five children born to David Aldona and Anna Pickett Hopkins. Hopkins' father, "Al," was an itinerant, jack-of-all-trades who enjoyed sports, and, on occasion, was known to wager on bowling matches. His mother, a devout Methodist, headed the local missionary society and was responsible for the family's move to the college town of Grinnell. This checkered set of parental values rubbed off on young Harry and remained indelibly inscribed on his personality and behavior. ${ }^{4} \mathrm{His}$ social gospel leanings were always balanced by his affection for the "good life." His close associate, Aubrey Williams, recalled that Hopkins was

a man's man and he loved the flesh pots ... He had a sweet tooth and a large appetite, but by a curious streak of nature, he also had a deep and abiding concern about the common man. ${ }^{5}$

Such an apparent paradox elicited many quotable descriptions, but none as enduring as Joseph E. Davies' remark that Hopkins "had the purity of St. Francis of Assisi and the shrewdness of a race track tout." ${ }^{\circ}$

At Grinnell College Hopkins was active in sports, an average student and president of the graduating class of 1912. As an undergraduate Hopkins came under the influence of the populist democracy-social gospel teachings of Professor Jesse Macy, and the internationalist views of Professor Edward Steiner. ${ }^{7}$ During the first decade of the twentieth century,

${ }^{4}$ Cf. biographical sources listed previously.

s"Notes on the New Deal," FDR Library, Aubrey Williams MSS, Box 11, File 44, 89.

${ }^{\circ}$ Sherwood, Roosevelt and Hopkins, 49.

'Cf. several biographical sources, especially Sherwood, Roosevelt and Hopkins, 16-21. 
academe experienced what Morton White called the "revolt against formalism." ${ }_{8}$ The rigid superstructure of Social Darwinism, with its emphasis on rugged individualism and laissez-faire, had buckled beneath the growing pressure applied by such social critics as Thorstein Veblen, Lester Frank Ward, William James, John Dewey and Charles A. Beard. Relativity replaced absolute certitude and pragmatism overthrew the old dogma, releasing many young graduates into the world (including Hopkins) with a dash of irreverence for those ideas and institutions which depended on archaic, mechanistic laws for their survival.

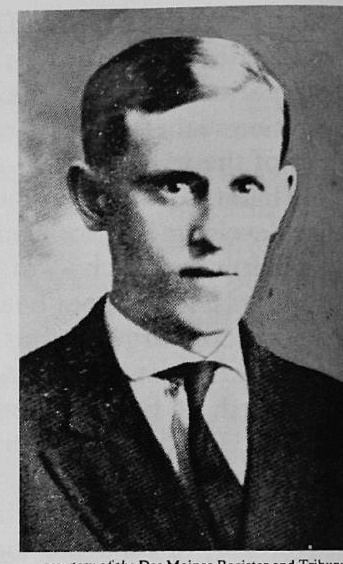

courtesy of the Des Moines Register and Tribunt

Harry Hopkins during his student days at Grinnell College.

Upon graduation, Hopkins considered a journalisti career, but Professor Macy dissuaded him by securing a posi tion for his student at a summer camp for a New York Cit, settlement house. From that moment, Hopkins found both th big city and social service irresistible. He worked for the Asso ciation for Improving the Condition of the Poor, the Board o Child Welfare, the Red Cross and, in 1924, he became the head of the New York Tuberculosis Association; Hopkins re mained there until 1931 when Governor Franklin D. Roosevel of New York asked him to join the Temporary Emergency Relief Administration, which provided relief for the state: unemployed. Hopkins assumed the chairmanship of thi agency in 1932 and followed FDR to Washington in the spring of 1933 to become Federal Emergency Relief Administrator As the head of the F.E.R.A., the Civil Works Administratio and the Works Progress Administration, Hopkins carved a impressive record of honest, efficient and imaginative servic

${ }^{8}$ Morton White, Social Thought in America, The Revolt Against Formalism (Boston: Bea con Press, 1949). 
to the one-third of the nation who were ill-fed, ill-clothed and ill-housed. When he joined the cabinet as secretary of commerce in December, 1938, Hopkins viewed the appointment as a reward for years of faithful service and a grand opportunity to build his image as FDR's protege and possible successor. However, near fatal illness ended these hopes and drained him of any political ambitions. When persistent poor health forced him to resign from the cabinet in August, 1940, Hopkins had already moved into the White House, where he worked and slept in the Lincoln room, next to the president's. Sherwood's account of their wartime partnership may never be equalled.

The Progressive movement stands as the political articulation of the "revolt against formalism," due to its support of many moderate reforms from 1900-1917. Hopkins' progressivism, at once humanitarian and pragmatic, was rooted in the social gospel wing of that broad national reform movement. His religious training and college education converged with his early work experiences and placed Hopkins in the swift current of social change that swept up many young reformers committed to an improvement in community and human services. Consequently, Hopkins spent most of his professional life "intimate with those aspects of our civilization that most people find it very convenient to be able to eliminate from their minds." 9 His daily exposure to the underside of American life engendered an interest in socialism and prompted Hopkins to support Morris Hillquit, the Socialist candidate for mayor of New York City in 1916. However, Hopkins was no ideologue; he had little use for the dogmatic preacher. He admired men of action and he cultivated the reputation of an active doer. "I belong to the school that does not talk about things-you do them." ${ }^{10}$ Hard work, political clout and efficient management, not moral exhortations and intellectual

${ }^{\circ}$ Fortune, 59.

${ }^{10}$ Hopkins Press Conference, May 23, 1940, FDR Library, Hopkins MSS, Box 118. 
gymnastics would carry the day. He frequently silenced his critics with rejoinders like, "Hunger is not debatable," and "People don't eat in the long run, they eat every day." "Hopkins left little doubt that his social commitment was genuine, and he justly earned his reputation as the "most aggressive social-economic reformer" in the New Deal camp. ${ }^{12}$

Sherwood detected "a kind of fanaticism in Hopkins' drive toward the objectives that he had to a large extent established for himself." ${ }^{13}$ Fanaticism, however, suggests the uncontrolled fervor of a true believer, which Hopkins was not; his earthy altruism made him an unlikely candidate to lead the singing of "Onward Christian Soldiers." His sympathies for the downtrodden burned brightly but not foolishly, since they "bore no obvious religious stamp." Hopkins seethed, but he never lost control. Like other progressives who rallied around the New Deal's colors, Hopkins had long since abandoned the old Emersonian dream of reforming people in favor of changing institutions. General Hugh S. Johnson, the first head of the National Recovery Administration, agreed that Hopkins was "obsessed with no such 'uplift' slush . . ." ${ }^{14}$

Hopkins demonstrated his practical humanitarianism when he chose the adminstrative path to personal success and public service. He was convinced early in his career that the liberal administrator could accomplish more than the socialist case worker. Hopkins often expressed embarrassment at the "nosy sentimentalist" image of the social worker. In truth, he stood in the vanguard of a new professionalism in the social service field. During the first quarter of the twentieth century, social work ceased to be the avocation of wealthy amateurs and became a recognized profession which required formal training and certification. Hopkins belonged to this new breed which gave neither alms nor friendship but professional service. He

"Sherwood, Roosevelt and Hopkins, 52, and Raymond Clapper, "Who is Hopkins?," Forum (December, 1937), 287.

${ }^{12}$ Charles, Minister of Relief. 166.

${ }^{13}$ Sherwood, Roosevelt and Hopkins, 49.

${ }^{14}$ Fortune, 59. John F. Carter, The New Dealers (New York: Simon \& Schuster, 1934), 184; Hugh S. Johnson, The Blue Eagle From Egg to Earth (Garden City: Doubleday, Doran \& Co., Inc., 1935), 426; William E. Leuchtenburg, Franklin D. Roosevelt and the New Deal (New York: Harper \& Row Publishers, 1963), 338-341. 
greatly admired his friend Porter Lee's direction of the New York School of Social Work; Lee "idealized the expert and technician" and he viewed the social worker as a "social engineer" who would mitigate human suffering through the efficient coordination of professional service. ${ }^{15}$ During the 1920s Hopkins spearheaded efforts to consolidate various public health agencies, while he managed the A.I.C.P. and the N.Y.T.A. (Association for Improving the Condition of the Poor, and New York Tuberculosis Association) efficiently. He once told an audience that he derived "no pleasure out of being identified with something that is supposed to be incompetent and inefficient." ${ }^{16}$ To insure proper administration, Hopkins consulted with various experts throughout his career, and he depended heavily on the expertise of public health officials in the 1920 s and businessmen and military officials in the 1930s.

Further proof of Hopkins' practical idealism was the introduction of work relief as a replacement for the dole. His political instincts told him that although work relief was more expensive than the dole, the former stood a better chance of receiving legislative approval. Schooled in the aphorisms of "Poor Richard" and other spokesmen for the Protestant work ethic, Hopkins subscribed to the notion that work was indeed a calling, a secular form of worship and a crucial ingredient in the individual's estimation of his own personal worthiness. He agreed with Benjamin Franklin's "Poor Richard" that "Tis hard for an empty bag to stand upright." ${ }^{17}$ In his book, Spending to Save, Hopkins wrote, "So far men and women, with few exceptions, have found no substitute for useful work to keep themselves sound of body and mind."' (p. 183). While in Europe in 1934, Hopkins spoke with Benito Mussolini about the Italian leader's public works program, and the American returned home more convinced to expand the use of work relief. ${ }^{18}$ Work relief projects benefitted both the individ-

\footnotetext{
${ }^{15}$ Charles, Minister of Relief, 211. Roy Lubove, The Professional Altruist (New York: Atheneum, 1969), 154-155.

${ }^{16}$ Harry L. Hopkins, Our Job (New York: W.P.A. Press, 1938), 8.

${ }^{17}$ Benjamin Franklin, Autobiography, edited by Jesse L. Lemisch (New York: The New American Library, 1961), 195.

${ }^{18}$ Memo on Mussolini Conversation for the President, July 26, 1934, FDR Library, Hopkins MSS, Roll 6.
} 
ual and society because the government now issued paychecks in return for public improvements. Work relief healed the damaged egos of many unemployed citizens, filling their empty sacks with hope, a sense of accomplishment, and the money to survive.

Unlike the Puritans and other proponents of the Protestant work ethic, Hopkins rejected the alliance between rugged individualism and laissez-faire and the attendant relationship between an individual's character and his chances for success. Hopkins bristled whenever critics blamed unemployment on laziness alone; Hopkins, on the other hand, blamed idleness on malfunctions in the political and economic system.

The poor are not poor because they're bad or lazy . . . I believe people are poor in the main because we don't know how to distribute the wealth properly . . . I believe the days of letting people live in misery, of being hungry, of moralizing about rugged individualism in the light of modern facts-I believe those days are over in America. ${ }^{19}$

Hopkins demonstrated his acceptance of governmental responsibility for effecting institutional reform by his forceful leadership in promoting and maintaining federal work relief activities during the New Deal years. The F.E.R.A. (Federal Emergency Relief Administration), C.W.A. (Civil Works Administration), and W.P.A. (Works Progress Administration) returned millions of alienated Americans to the national mainstream during the 1930 s, salvaged their self-esteem and de-fused the threat of social revolution. When critics pelted Hopkins with charges of "boondoggling,"” the crusty Iowan reminded his detractors that relief money and labor had constructed many new schools, hospitals, bridges, airports, highways, post offices, recreational facilities, military bases, and made other public improvements. The federal work relief program offers strong testimony of the New Deal's revolutionary response to the Great Depression; Hopkins and FDR succeeded in making the federal government dramatically more responsive to the needs of America's army of unemployed.

${ }^{19}$ Hellman, "House Guest," 29, 34.

*This was a pejorative term directed at "make-work" projects such as leaf-raking and the like. 
Sherwood believed, quite rightly, that, beyond the visible results of work relief "were the things that were saved from obsolescence within the relief workers themselves, including their self-respect and their essential patriotism and, most importantly, their skills." 20

Although he may never have read Herbert Croly's The Promise of American Life, Hopkins was a democratic nationalist who approved of Hamiltonian means to achieve Jeffersonian ends. Croly called for the transformation of democratic destiny into national policy.

In becoming responsible for the subordination of the individual to the demand of a dominant and constructive national purpose, the American state will in effect be making itself responsible for a morally and socially desirable distribution of wealth. ${ }^{21}$

Charles Forcey agreed that Croly wanted a "strong, active, militarily powerful national government to serve the ends of social justice, democracy and world peace." ${ }_{22}$ Hopkins saw little merit in an unregulated system which spawned both waste and want. He welcomed the New Deal as the "effort of a free people to achieve under (sic) democratic form of government the blessings of a highly organized industrial order." ${ }^{23}$ Hopkins applauded the New Deal for attempting

a policy of reconstruction in which the social order will be amended to include the right of people to work and an assurance of benefits for the workers that are not based on the whims of the individual but are grounded in the fabric of social justice. ${ }^{24}$

Hopkins fretted more about individual human needs rather than political rights. He diagnosed the social and economic ills that festered beneath the surface of democratic capitalism and foresaw the collapse of the American way of life unless an enlightened government intervened immediately to treat the nation's sores. Hopkins convinced the president to support his work relief plans and, according to Searle Charles, Hopkins

${ }^{20}$ Sherwood, Roosevelt and Hopkins, 76.

${ }^{21}$ Herbert Croly, The Promise of American Life (New York: E. P. Dutton \& Company, Inc., 1963, with an introduction by Charles Forcey), 23.

${ }^{22}$ Ibid, xi.

${ }^{23}$ Harry Hopkins, "The War on Distress," Today I. December 16, 1933, 8-9, 23; New Deal Thought, edited by Howard Zinn, (New York: Bobbs-Merrill Company, 1966), 158.

${ }^{24}$ Ibid, 158. 
deserves much of the credit for keeping millions of unemployed Americans during the Great Depression "aligned with our federal government and loyal to our democratic way of life." ${ }^{25}$ This achievement assumed greater significance as war clouds thickened and America gravitated closer to the eye of the storm. Hopkins fully understood the importance of "imponderable gains" such as the

restoration of the confidence of our people in their form of government, the conservation of the physical and spiritual welfare of our people, the enrichment of our social environment with vast public improvements. ${ }^{26}$

As the Axis powers grew more menacing, Hopkins articulated his concern for the survival of the American way of life.

. . . the preservation of our system of free enterprise is no longer the American dream: it is the American imperative. It is imperative that freedom of opportunity be maintained for all who can contribute to our national well-being. It is imperative that the responsibilities, and the benefits as well of our industrial system be broadly shared, so that the success of the system will enlist the loyalty, the energies and the capacities of a free and united people. ${ }^{27}$

Herbert Croly could not have said it better.

Hopkins functioned well in an emergency and the New Deal experience enabled him to function well in a war emergency. Hopkins, the ambitious crusader, was susceptible to and in favor of a nationalistic campaign which utilized the analogue of war to mobilize the energies of the citizenry. Many progressives would agree with philosopher William James, who sought a "moral equivalent to war" which preserved the vital martial virtues necessary for survival and progress and would "inflame the civic temper as past history has inflamed the military temper." ${ }^{28}$ Theodore Roosevelt's New Nationalism was the political articulation of Croly's democratic nationalism and James' mobilization psychology. In order to enact reform and preparedness measures after 1916, President Wood-

${ }^{25}$ Charles, Minister of Relief, 248.

${ }^{26}$ Hopkins Speeches, 1938, FDR Library, Hopkins MSS, Speech File, Box 5.

${ }^{27}$ Harry L. Hopkins, "Des Moines Economic Club Speech," Vital Speeches, March 15, $1939,338$.

${ }^{28}$ William James, The Moral Equivalent of War and Other Essays, edited by John K. Roth (New York: Harper \& Row, Publishers, 1971), 14. 
row Wilson ditched his plans for a passive Jeffersonian state and snatched the Hamiltonian idea of a strong central government which his opponent Theodore Roosevelt had supported. World War I afforded many reformers the historic opportunity to combat illiberalism both at home and abroad. Wilson's messianic rhetoric attracted many totalitarian liberals who used the war emergency to treat many social ills at home. War socialism, as it was called, demonstrated the efficacy of issuing a call to arms as a means of effecting a "blueprint for Utopia." ${ }^{29}$ Hopkins succumbed to the infectious appeal of the Progressive movement and the First World War. Before 1917, he had served in the trenches of urban reform, and when war came, he tried unsuccessfully to enlist in the Wilsonian crusade. Although defective eyesight prevented him from serving in the trenches on the Western Front, Hopkins plunged into his duties as Red Cross chief for the southern region with characteristic elan. The post-war disillusionment failed to dampen Hopkins' spirits; he continued his headlong pursuit of personal advancement and social change. According to one student of the 1920 s, social reformers "evidenced a remarkable vitality and imagination" during that nadir of national political leadership between the war and the New Deal. ${ }^{30} \mathrm{Hop}$ kins kept the faith, practiced the craft of the professional altruist and helped bridge the gap between the Progressive movement and the Franklin Roosevelt era.

Otis Graham discovered that a majority of ex-progressives opposed the New Deal's social legislation, while municipal reformers, settlement house workers, ministers and social workers tended to support FDR's policies. ${ }^{31}$ The Hopkins story certainly supports these findings. He naturally gravitated toward crises, and in the early 1930 s his reputation brought him to the attention of the man who was destined to wield more political and military power than anyone in history. In his first inaugural address, FDR issued a "call to arms" and asked the

${ }^{29}$ William E. Leuchtenburg, "The New Deal and the Analogue of War," The Impact of World War I, edited by Arthur S. Link (New York: Harper \& Row, Publishers, 1969), 57-70. 266.

${ }^{30}$ Clarke A. Chambers, Seedtime of Reform (Ann Arbor: University of Michigan, 1967),

${ }^{3}$ Otis Graham, An Encore for Reform: The Old Progressives and the New Deal (New York: Oxford University Press, 1968), 197. 
nation for "broad executive power that would be given to me if we were in fact invaded by a foreign foe." ${ }^{32}$ Arthur Schlesinger Jr. believed that Hopkins was convinced that "all walls would fall before the man of resource and decision." ${ }_{33}$ The president's use of the analogue of war jogged the memories of many reformers who welcomed another chance to reorganize society. Roosevelt summoned Hopkins from Albany in 1933, whereupon the latter accepted the Washington post, took a $\$ 3,000$ pay cut and spent over $\$ 5,000,000$ during his first two hours on the job from a makeshift office in the hall. The president's contagious optimism and forceful leadership impressed Hopkins. The head of the F.E.R.A. wrote in 1933 that "The dynamics of the president's program and his personality have galvanized the people into action." ${ }^{34}$ Hopkins viewed the New Deal as the "chance of a lifetime" to correct long-festering social problems; he vowed to experiment with the relief funds, and if the schemes failed, "the world will not come to an end." 35

FDR spoke of a "trained and loyal army willing to sacrifice for the good of a common discipline" and Hopkins remarked that

We have these great armies of government-trade recovery, public-works relief, U.S. employment service-all marching hand in hand under the direction of the president. ${ }^{36}$

It was no mere coincidence that both men chose the metaphor of a disciplined national army engaged in a great struggle. Hopkins and the president had learned from the recent past that the American people could be mobilized in support of domestic reform as well as a war to end all wars. Hopkins marched to the quickening drum beat which led the Rooseveltian army into battle against the forces of want and waste. He distinguished himself as a dependable staff officer and a resourceful tactician who ably executed the general's grand strategy for victory. Rexford Tugwell claimed that Hopkins

${ }^{32}$ Franklin D. Roosevelt, Looking Forward (New York: John Day Company, 1933), 267.

${ }^{33}$ Arthur M. Schlesinger, Jr., The Age of Roosevelt, II, The Coming of the New Deal (Boston: Houghton, Mifflin, 1965), 265.

${ }^{34}$ Hopkins, "The War on Distress," 158.

${ }^{35}$ Proceedings of National Conference of Social Work, 1933, (Chicago: University of Chicago Press, 1933), 69.

${ }^{36}$ Ibid, 70; Roosevelt, Looking Forward, 267. 
saw himself mainly "as an operator, not as a statesman.", 37 The loyal soldier was "an extremely ambitious man and once he had established a position for himself he started restlessly to look toward the next step upward." ${ }^{38} \mathrm{His}$ abandonment of case work in favor of an administrative career marked the beginning of his odyssey to "establish" himself as a versatile administrator of public health and relief.

During the first two years of the New Deal, Hopkins eschewed politics, but in 1935 his waxing ambitions surfaced in the "battle of relief" with Harold Ickes. Hopkins cut his political teeth in this internecine struggle which thrust the W.P.A. into the front ranks of the president's recovery campaign. Hopkins' struggle with Secretary of the Interior and Public Works Administrator Ickes erupted over who would control the expenditure of the $\$ 4,800,000,000$ Emergency Relief Appropriation of 1935 . Ickes preferred to spend money scrupulously on skilled labor for the construction of massive public works, while Hopkins elected to spend money quickly for wages on a variety of inexpensive projects. When his approach received the president's approbation, Hopkins "became overly influenced by the power of his position," thus producing a "conflict between the altruistic social worker and a shrewd politician in the making [which] shaped the rest of Hopkins' career as a relief administrator." ${ }^{39}$ Hopkins recalled,

I thought at first I could be completely non-political. Then they told me I had to be part non-political and part political. I found that was impossible, at least for me. I finally realized there was nothing for it but to be all-political. ${ }^{40}$

Hopkins reached out for power in the 1930s wherever it lay, including the Army and the White House; after FDR's reelection in 1936 Hopkins acquiesced in the increasing politicization of the W.P.A. ${ }^{41}$ This development coincided with the surfacing of Hopkins' presidential ambitions. 544-555.

${ }^{37}$ Rexford G. Tugwell, The Democratic Roosevelt (Baltimore: Penguin Books Inc., 1969),

${ }^{38}$ Sherwood, Roosevelt and Hopkins, 77.

${ }^{30}$ Charles, Minister of Relief. 93.

${ }^{40}$ Sherwood, Roosevelt and Hopkins. 68.

${ }^{4}$ "Arthur M. Schlesinger. The Age of Roosevelt, III. The Politics of Upheaval (Boston: Houghton, Mifflin, 1966), 356. 
Hopkins wanted history to record that he had indeed harbored presidential ambitions and that "he worked and schemed to further them." ${ }^{42}$ Hopkins began to take himself seriously as a presidential candidate soon after the president's landslide victory in 1936. Early in 1938, FDR spoke candidly with Hopkins about the 1940 Democratic nominee and the president indicated that he would support Hopkins' efforts to secure the party's presidential nomination. FDR became Hopkins' unofficial campaign manager and advised his relief administrator to cultivate a more favorable impression "among the more conservative elements, and particularly the business community." The president affixed his imprimatur to Hopkins' campaign by arranging for the two men to be photographed together in public. ${ }^{43}$ Despite this support, Hopkins' career suffered two serious setbacks: the president's reorganization bill failed to win congressional approval, thus depriving Hopkins of a cabinet post as secretary of public welfare; and the Shepard committee conducted extensive investigations of the political activities of state W.P.A. leaders during the abortive purge of conservative Democrats in 1938. FDR then rescued Hopkins' career by appointing him secretary of commerce on Christmas Eve, 1938.

Hopkins accepted the appointment as a reward for years of faithful service and he declared his intention to streamline the Commerce Department and make it a more effective instrument in promoting business recovery. His new position removed him from the narrow channel of work relief and launched him into the broad sea of private employment. Publicly he described his new job thusly:

Instead of working for the one-third of the population on the lower rungs of the economic ladder, I consider this job one more closely identified with the two-thirds of the population earning their living by what we consider to be the normal process of our economic system. ${ }^{44}$

Privately, he wrote his brother Lewis that "I don't know quite what this job is all about yet but I hope to find out pretty

${ }^{42}$ Sherwood, Roosevelt and Hopkins, 92.

${ }^{43}$ Ibid, 93-99.

${ }^{44}$ Harry L. Hopkins, "Des Moines Economic Club Speech," op. cit., 336. 
soon." ${ }^{45}$ Hopkins devoted the bulk of his time to the expansion of our foreign markets and to the increasingly important question of national preparedness. Hopkins courted some of the nation's leading industrialists, and those who became quite friendly, most notably Averell Harriman and Edward Stettinius, were called “Hopkins' tame millionaires." 46 These business connections proved invaluable as war approached and close cooperation among political, military and business leaders became essential to the nation's survival. He fought German inroads into our Latin American trade, stockpiled strategic materials, coordinated preparedness activities of business and military leaders and monitored the productive capacities of certain key industries. Nevertheless during his twenty-month tenure, Hopkins' accomplishments fell short of his expectations due to recurring ill health after a visit to his home state, Iowa, in February, 1939. Despite the illusion his aides created that Hopkins was a "dynamo of activity," the new commerce secretary spent most of his tenure recuperating in his Georgetown home. ${ }^{47}$

Perhaps the single most important factor which governed his personal ambitions after 1937 was his failing health. Before departing for Europe in July, 1934, Hopkins wrote his brother that his second wife, Barbara Duncan Hopkins, would accompany him because, "life is far too short to leave her behind." ${ }^{48}$ Hopkins had already developed a painful duodenal ulcer that required a strict diet. His reformer's impatience and short term outlook added to his sense of urgency. His worst fears were confirmed in October, 1937 when his wife succumbed to cancer and Hopkins discovered that he too suffered from the dread disease. Surgeons at the Mayo Clinic removed most of his stomach and arrested the cancer, but Hopkins nearly died of the cure. After the operation, the patient developed serious digestive problems that plagued him for the remainder of his life. Although he enjoyed relatively good health in 1938, Hopkins suffered a severe relapse after his Roll 3.

${ }^{45}$ Harry Hopkins letter to Lewis Hopkins, February 9, 1939, FDR Library, Hopkins MSS,

${ }^{46}$ Sherwood, Roosevelt and Hopkins, 110-111.

"Ibid, 112-113. 3.

${ }^{48}$ Harry Hopkins letter to Lewis Hopkins, June 29, 1934, FDR Library, Hopkins MSS, Roll 


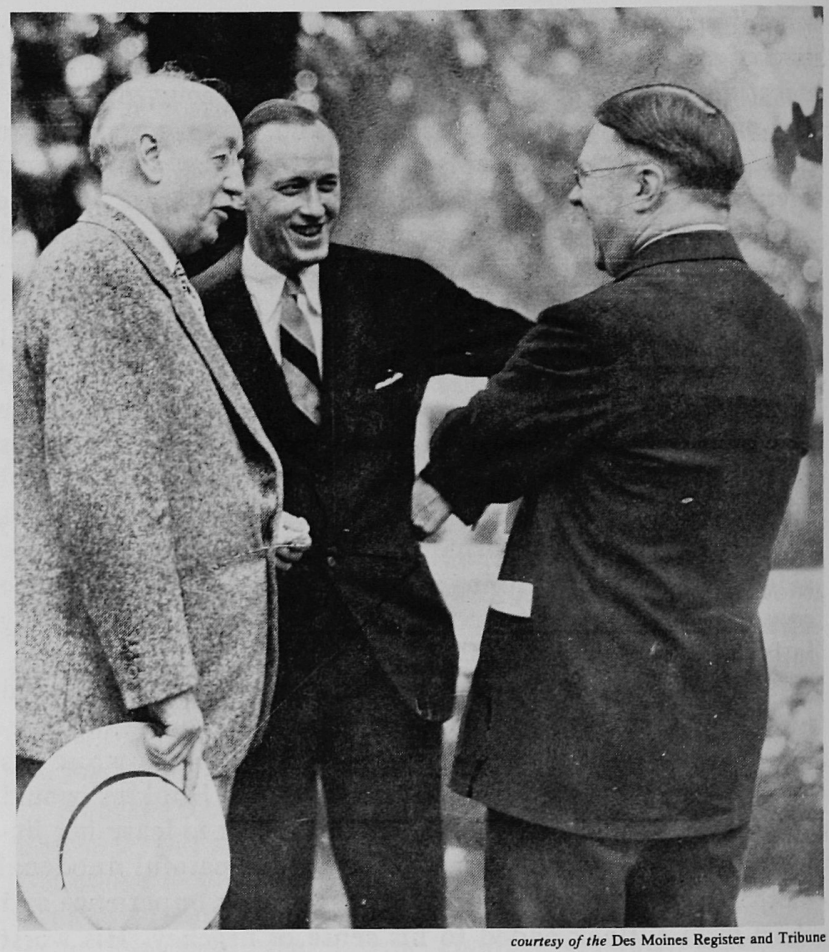

Hopkins (center) talks with Governor Clyde L. Herring (left) and John F. Nollen, president of Grinnell College, during a visit to the campus in the summer of 1935.

Iowa visit in February, 1939. The cancer never recurred, but Navy doctors must be credited with keeping Hopkins alive through the Second World War by treating his acute malnutrition with experimental drugs and a stringent diet. At some point during that summer of 1939, when Hopkins lay near death, he must have realized that, even if he should recover, his latest setback precluded him from seeking the Democratic presidential nomination in 1940 . When he did recover, Sher- 
wood approved of the transforming effect which illness had on his character.

Near fatal illness drained him of all personal ambition and converted him into the selfless individual who rendered such great service to the president during the war years. ${ }^{49}$

Sherwood also remarked that the New Deal provided ideal combat training for FDR, Hopkins and the American people, but he exaggerated the suddenness of Hopkins' transformation from a dedicated reformer into a fanatical warrior after 1940. Hopkins' interest and involvement in national preparedness did not occur overnight, but was, rather, one of the many gardens Hopkins tended from 1935-1938. The years as commerce secretary marked the demise of Hopkins' political ambitions, and the evolvement of national defense as his foremost concern. He told an interviewer in 1943 that "The war is a damn personal thing to me ..." ${ }^{50}$ Hopkins became so engrossed in the war effort that he shocked Sherwood with his irritation at the complaints of "god damn New Dealers" who acted as if there were no foreign peril. ${ }^{51}$ The New Deal's use of the analogue of war conditioned Hopkins for battle, but his W.P.A. experience provided more of a substantive influence on the evolution of Hopkins the zealous preparedness worker.

Hopkins presided over the expenditure of relief money for national defense purposes before 1940. Although the Neutrality Act of 1935 forbade the use of relief money or labor for the construction of war material, the W.P.A. alone had managed to spend $\$ 432,272,000$ on national defense projects in conjunction with several sponsors by June 30,1940 . This included $\$ 182,197,000$ on airport construction and renovation, $\$ 154,131,000$ for various projects at Army bases, $\$ 50,152,000$ for the National Guard, $\$ 44,591,000$ for the Navy and $\$ 1,201,000$ for the Coast Guard. ${ }^{52}$ One military newspaper claimed that between 1935 and 1939, "when regular appro-

${ }^{49}$ Sherwood, Roosevelt and Hopkins, 113.

${ }^{50}$ Hellman, "House Guest," 30.

${ }^{51}$ Sherwood, Roosevelt and Hopkins, 279.

${ }^{52}$ W.P.A. Final Report (Washington: U.S. Government Printing Office, 1943), 118; Treasury Report on Emergency Relief Appropriation, 1935-1941 (Washington: U.S. Government Printing Office, 1942), 18; Report on Progress of W.P.A. Program, 1938, 47; National Archives, W.P.A. Records, National Defense File. Howard Hunter Report, August 12, 1940, National Archives, W.P.A. Records, New Deal File. 
priations for the armed forces were so meager, it was th W.P.A. worker who saved many Army posts and Naval sta tions from literal obsolescence." ${ }_{53}$ In the wake of FDR', Quarantine Speech of October, 1937 and the bombing 0 the Panay two months later, the W.P.A. deflected charges 0 "boondoggling" by stressing the military benefits accruec from work relief projects. Wider, smoother runways accom modated larger, faster military airplanes; reconditioned Arm bases improved morale as well as the plumbing, transporta tion, machinery, etc.; deeper, safer harbors promoted greate naval readiness; modern National Guard armories served a civilian community centers when not in use for military drills. ${ }^{54}$ In these operations, Hopkins utilized the expertise 0 the Army Corps of Engineers to approve plans and monito the progress of the work relief projerts. Hopkins came to ad mire the engineers' efficiency, their apolitical reputation and their ability to work under emergency conditions. Hopkin placed several engineers in sensitive urban centers and one Colonel Francis Harrington, advanced from Hopkins' chie engineering aide to become his successor in December, $1938 .^{5}$ An associate of Hopkins, Colonel Lawrence Westbrook, con sidered Hopkins' work with these officers of inestimable value in the education of Harry Hopkins, for it "prepared the way for the close cooperation that was so effective during World War II." ${ }^{56}$ Two leading generals, George Marshall and Henry Arnold, familiar with this connection, recognized in Hopkins a valuable ally who would assist them in the acquisition of greater support for national defense.

FROM THE SUMMER of 1938 until his illness of February 1939, Hopkins publicly articulated attitudes that he actec upon in private. His intensifying involvement in national preparedness was reflected in his speeches, which reiterated the necessity of building national security upon the firm footing of

${ }^{53}$ Army and Navy Register, May 16, 1942, 27.

${ }^{54} \mathrm{Cf}$. sources in fn. 52 and Millions For Defense (Washington: Federal Works Agency 1940). This election year report may be found in both the Hopkins and John M. Carmody MS at the FDR Library. Carmody was the head of the FWA.

${ }^{55}$ Sherwood, Roosevelt and Hopkins, 75-76.

${ }^{50}$ Ibid, 76. 
domestic recovery. Hopkins convinced the president to support deficit spending and augment federal funds for work relief; the W.P.A. chief regarded these expenditures as a wise investment in the nation's future and a salient portion of the democratic imperative which compelled America to retain the loyalties of her citizens. At this time Hopkins also enlarged his direct involvement in military preparedness.

During the Munich crisis of September, 1938, Hopkins visited several West Coast airplane factories and measured their productive capacities. Upon his return from a second visit in October, Hopkins recommended to the president that the W.P.A. build eight to ten new aircraft plants for the War Department to operate. Although this plan won the initial endorsement of FDR, it was eventually scrapped. ${ }^{57}$ Nevertheless, this effort marked the beginning of Hopkins' deep involvement in national preparedness. As secretary of commerce, Hopkins persisted in his efforts to strengthen America's defense posture. He organized this country's resistance to Germany's clandestine economic expansion into Latin America. According to the young Nelson A. Rockefeller, Hopkins "was concerned about Nazi penetration in Latin-America-in business, finance, politics-all the way across the board." 58 The policy of the "Good Neighbor" emphasized inter-American cooperation and "hemispheric solidarity" as opposed to the infamous policy of the "Big Stick." Hopkins also cemented the government's alliance with prominent businessmen and military leaders to fortify our nation's defense. As an organizer of expertise, Hopkins became a charter member of the "industrial-military complex" when the latter was an embryonic team, not the menacing "power elite" of the post World War II era. ${ }^{59}$ On the evening of. May 10, 1940, as

${ }^{57}$ Henry Morgenthau, "Report on Staff Meeting," FDR Library, Morgenthau Diaries, Book 146, 280, and "Notes on November 14, 1938 Meeting," Book 150, 338; John M. Haight, Jr., American Aid to France (New York: Atheneum, 1970), 53-55; General Henry Arnold, Memo on November 15, 1938 Meeting, FDR Library, FDR MSS, Official File 25-T.

${ }^{58}$ An excellent so:urce is Rockefeller Archives, Unpublished MSS, 144-145, n.d.

${ }^{59}$ For penetrating analyses of the origins of this "complex," cf. Paul A. C. Koistinen's two articles, "The 'Industrial-Military Complex' in Historical Perspective: The InterWar Years," The Journal of American History, LVI (March, 1970), 819-839; and "The 'Industrial-Military Complex' in Historical Perspective: World War I," Business History Review, XLI, No. 4 (Winter, 1967), 378-403. 
Hitler's war machine invaded the Low Countries, Harry Hopkins came to dinner at the White House and remained for more than three years, working daily at the president's side to insure this nation's survival.

Hopkins was a moderate Christian Socialist who maintained throughout his career that society was responsible for providing work and basic human services to those who fell victim to the vicissitudes of the national economy. He called for an end to the double standard which sanctioned governmental assistance to business and industry while refusing the same to those powerless millions at the bottom of the social ladder. America could no longer afford to acquiesce in socialism for the rich and demand free enterprise for the poor. Despite his reservations about the merciless nature of laissez-faire capitalism, Hopkins genuinely admired our constitutional republican system of government. He believed our political system could and must effect institutional reform which guaranteed the blessings of social justice to all citizens, not merely a chosen few. Invariably honest, Hopkins found in public health and relief administration abundant opportunities to advance the cause of mankind and his own career; however the man who spent billions to alleviate poverty died a poor man. "Harry the Hop" sought power not wealth, and in this undertaking he was eminently successful. He won the confidence of President and Mrs. Roosevelt, and advanced through the New Deal ranks to become the second most powerful man in America. With all the attendant blemishes of ambition aside, the historical Hopkins was a professional altruist, an ambitious crusader and a member of the administrative breed who served his president, his country and his fellow man-and served them well. 
Copyright of Annals of Iowa is the property of State of Iowa, by \& through the State Historical Society of Iowa and its content may not be copied or emailed to multiple sites or posted to a listserv without the copyright holder's express written permission. However, users may print, download, or email articles for individual use. 